\section{Pressure grows for US to resume chemical weapon production}

\author{
David Dickson reports from Washington on a \\ shift of emphasis in Defense Department thinking
}

PRESSURes are again growing in Washington for the United States to resume production of chemical weapons, on which a moratorium was imposed in 1969 following protests about the use of incapacitating and defoliant agents in Vietnam.

The pressures are the result of concern within the Department of Defense at the build-up of chemical weaponry by the USSR. They also reflect uncertainty about the progress of the chemical disarmament talks currently taking place between the US and the USSR in Geneva.

There has recently been a steady upgrading in the Defense Department's Chemical Corps, part of a general shift in focus towards possible nonnuclear conflict between the USSR and NATO forces in Europe. In addition, Defense Secretary Harold Brown announced last month that 900 Weteye bombs, the most up-to-date nerve-gas munitions in the US stockpile on which production was halted in 1969 and which had previously been scheduled for destruction, are to be retained because of their "deterrent advantage".

And sources in Washington now say that the administration is considering a likely request from the Defense Department for funds to initiate steps that could lead to the production of so-called binary weapons.

Binary weapons get their name from the fact that they contain two separated chemicals, each non-lethal on their own, which are placed in an artillery shell and combine on firing to form a nerve gas. (One design, for example, involves combining the liquid ethyl - 2 - diisopropylaminoethylmethylphosphonite with one of the solid dimethylpolysulphides.) R\&D programmes have already been completed for one binary artillery shell, and are expected to be completed soon for another shell and a nerve gas bomb.

The Pentagon has been working on binary munitions since the late $1960 \mathrm{~s}$, intending that they should eventually replace the more conventional forms of nerve-gas delivery systems-for example since they are easier to handle, store and transport.

However budget requests for money to begin the production of binary munitions were denied by the US Congress in both 1974 and 1975. At the time Congress felt higher priority should be given to developing protec- tive measures for US troops; it was claimed, for example, that reducing the effectiveness of a chemical attack would itself increase pressures for disarmament.

Many of Congress's demands for placing the emphasis on protection have now been met. Agreement to increase spending on protective measures against chemical attack was reached by the heads of NATO countries last month.

One reason given by Congress for rejecting the demand for binaries was that such a decision should depend on the progress of the bilateral talks on chemical disarmament which were originally agreed by President Nixon and $\mathrm{Mr}$ Brezhnev at their Moscow summit meeting in 1974.

These talks started in Geneva in August 1976, and have just recessed for the summer after seven months of discussion. Opinions about their progress vary. Some point to the agreement reached on a number of points of principle as indicating that important progress has been made. Others are more cautious. Professor Matthew Meselson, Cabot professor of natural sciences at Harvard University and editor of Chemical weapons and chemical arms control (published last

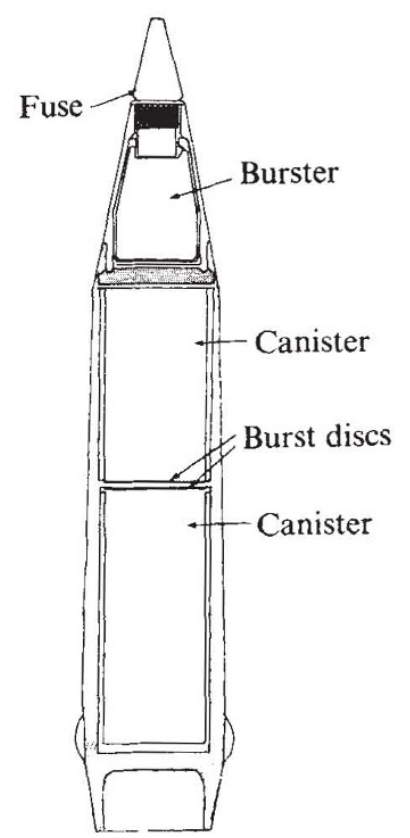

Cross section of a binary artillery shell: will Carter accept a request that a factory be built capable of producing such weapons and other designs now being studied? month by the Carnegie Endowment for International Peace, 11 Dupont Circle NW, Washington DC 20036) says that the talks have now reached a cross-roads, and that the real business is only just beginning.

A particular sticking point has been the problem of verification. Both sides now accept that this must be included in any agreement, and that it should be based on a combination of national and international arrangements. However, a communique issued last month admitted there was no agreement on verifying the destruction of stocks or a ban on manufacture.

Pressing for greater efforts towards chemical disarmament at the United Nations Disarmament Conference in New York two weeks ago, British Prime Minister James Callaghan repeated his promise that Britain, which has already tabled its own draft convention on chemical weapons, would accept inspection of relevant chemical manufacturing plants, as well as any other measures needed to underpin future agreements.

However, elsewhere such acceptance seems a long way off. With little chance of an immediate agreement, some Defense Department officials are using the opportunity to restate the case for upgrading the US's deterrent capacity. They are arguing, for example, both that the defensive measures requested three years ago by Congress have now been taken care of, and that many of the existing stocks of chemical weapons are deteriorating.

Two years ago a request to include $\$ 15$ million in the budget message to Congress to build a binary munitions production plant-although not to begin production itself, which would have required further Congressional approval-was rejected by President Ford largely on the grounds that it might prejudice the Geneva talks.

However budgetary recommendation for the fiscal year 1980 are now being prepared for submission to President Carter, and a similar request-although slightly larger to allow for inflation and other factors-is expected to be made again by the Defense Department.

Whether this request will have any greater success than it predecessor could depend on the case for costeffectiveness of chemical weapons that the Pentagon, facing cost over-runs in more conventional areas of the Defense Procurement Programme, can make with the president's economic advisers.

But if it does get through in the president's submission to Congress, a rough ride can be predicted on Capitol Hill, particularly from those supporters of disarmament who claim that any such act can only increase the likely use of chemicals in war. 